\title{
Glenstone Methods
}

\section{Research Fellow:}

Emma Mendel

Lecturer

University of Virginia

Research Assistant:

Chloe Nagraj

MLA Candidate

University of Virginia

\section{Firm Liaison:}

Seth Rodewald-Bates

PWP Landscape Architecture

This investigation was conducted as part of the Landscape Architecture Foundation's 2019 Case Study Investigation (CSI) program. CSI matches faculty-student research teams with design practitioners to document the benefits of exemplary high-performing landscape projects. Teams develop methods to quantify environmental, economic and social benefits and produce Case Study Briefs for LAF's Landscape Performance Series.

To cite:

Mendel, Emma, and Chloe Nagraj. "Glenstone Methods" Landscape Performance Series. Landscape Architecture Foundation, 2019.

https://doi.org/10.31353/cs1561

The full case study can be found at: https://landscapeperformance.org/case-studybriefs/glenstone 


\section{Overview}

\section{Introduction:}

Glenstone is a contemporary art museum with nearly 300 acres of landscape that was designed over two phases during the course of fifteen years. Building on PWP's work with the Glenstone Foundation over this period, the firm is actively engaged in an ongoing master plan process that continues the Foundation's mission of seamlessly integrating art, architecture, and nature. Focused on expanding experiential, programmatic, and ecological goals, the master plan seeks to provide a framework for Glenstone's continued evolution in the years to come. For the purpose of this case study investigation, the research team focused on Phase 1 and Phase 2. Prior to Phase 1 construction, the majority of the landscape was graded as a subdivision.

\section{Research Strategy:}

This case study investigation seeks to quantify several of the main goals for the project: to create a contemplative and integrated experience of nature, art, and architecture; to revitalize the formerly fragmented subdivision plots into a more ecologically sound landscape; and to engage a sustainable, systems approach to landscape maintenance, water management, reforestation, and meadow regeneration.

The evaluation of Glenstone's landscape performance uses two main analysis techniques: comparative analysis, which compares primary and secondary data collected on-site, from project designers, and from contractors to industry or local averages or traditional design strategies; and cross-sectional survey, which collects data from a specific population of interest (in this case, museum visitors) at a single point in time.

\section{Data Collection Methods:}

The research team relied on design drawings and pre-construction analysis provided by PWP and sub-contractors, on-site observations conducted by the research team on site visits from April-July 2019, and interviews with Glenstone staff. In keeping with the format of the Case Study Investigation program, benefits are organized into three categories: Environmental, Social, and Economic. 


\section{Environmental Benefits}

\section{- Restored or improved soils on 120 acres. In one representative sample, soil testing showed a 300\% increase in organic matter between 2010 and 2016.}

\section{Methods:}

During construction, 40,000 cubic yards of topsoil was stripped and stockpiled in a single contiguous area that was overseeded with cover crops to enhance the soil's fertility. ${ }^{1}$ Soil collection and protection measures put in place during construction included harvesting stockpiled soil only when needed to limit disturbance, and using tracked rather than wheeled vehicles to transport soil to limit compaction. In total, 120 acres of restored or improved soil was constructed during the course of this project, as determined by area takeoffs by PWP.

Glenstone and PWP worked with the University of Maryland and soil consultants throughout the process to map the site and determine existing soil properties. Before Phase 1 construction, when the first $0-12$ " of soil were tested, the soils in these test sites were found to have low to medium nutrient levels, very low levels of phosphorous with normal micronutrient levels, and low cation exchange capacity. The $\mathrm{pH}$ of the tested soils ranged from 5.4 to 7.5 , which is acceptable for non-ericaceous plantings. The soil structure was found to be well-drained before construction, and measures were put in place to ensure that the well-drained soil onsite would be collected, stockpiled, and protected during construction.

Soil health was tested before and during construction, and Glenstone employs a full-time soil technician who continuously monitors and tests soils. Soils onsite are amended using compost tea and compost produced onsite. Synthetic chemical fertilizers are not used to amend soil.

Soil samples were collected and analyzed by consultants and by Glenstone's soil technician to determine and monitor soil health properties. This soil testing data was provided by PWP and Glenstone. Laboratory testing of topsoil samples (0-12") indicated that samples taken from test pits throughout the site were relatively consistent and likely represent similar soil types, with a USDA classification of sandy loam to clay loam. ${ }^{2}$ Soil test results from before Phase 1 construction and during Phase 2 construction can be found below. Soils were also tested prior to Phase 2 construction.

\footnotetext{
${ }^{1}$ Glenstone Whitepaper on Conservation

${ }^{2}$ Pine \& Swallow Environmental, Existing Horticultural Soil Conditions Report, 2013
} 
Calculations:

\begin{tabular}{|l|l|l|l|l|l|}
\hline Indicator & $\begin{array}{l}\mathbf{2 0 1 0} \\
\text { Value }\end{array}$ & 2010 Rating & 2016 Value & 2016 Rating & $\%$ Change \\
\hline Organic Matter & $\begin{array}{l}1.6 \%, 73 \\
\text { ENR lbs/A }\end{array}$ & Low & $\begin{array}{l}6.4 \%, 150 \\
\text { ENR lbs/A }\end{array}$ & High & $300 \%$ \\
\hline Phosphorous & $11 \mathrm{ppm}$ & Very Low & $19 \mathrm{ppm}$ & Low & $72 \%$ \\
\hline Potassium & $146 \mathrm{ppm}$ & High & $172 \mathrm{ppm}$ & High & $18 \%$ \\
\hline Magnesium & $183 \mathrm{ppm}$ & High & $204 \mathrm{ppm}$ & High & $11 \%$ \\
\hline Calcium & $948 \mathrm{ppm}$ & High & $1546 \mathrm{ppm}$ & High & $63 \%$ \\
\hline pH & 7.1 & & 7.3 & & $50 \%$ \\
\hline $\begin{array}{l}\text { C.E.C (Cation } \\
\text { Exchange } \\
\text { Capacity) }\end{array}$ & $\begin{array}{l}6.6 \\
\text { meq/100g }\end{array}$ & & $9.9 \mathrm{meq} / 100 \mathrm{~g}$ & & \\
\hline
\end{tabular}

Fig. 1: Soil testing results from one test pit at Glenstone. Source: PWP Landscape Architecture

\section{Sources:}

Area takeoffs of restored or improved soils provided by PWP Landscape Architecture Whitepaper on Conservation, soil testing results provided by Glenstone Soil testing results, soil plan provided by PWP

\section{Limitations:}

Soil testing results reflect pre-Phase 1 construction and during Phase 2 construction. In this analysis, testing results reflect one soil test pit. Throughout construction and after Phase 2, soils are tested from throughout the site. As such, more granular data is available than what was analyzed for the purpose of this case study.

- Manages the 1-inch, 24-hour rain event with a total treatment capacity of 49,000 cu $f t$ in bioretention facilities, pervious pavement, and a cistern.

Methodology: Stormwater management for Glenstone was designed in accordance with the state of Maryland's Environmental Site Design (ESD) Process and Computations for the treatment of the 1 inch, 24 hour rain event. The design approach took into account the results of a Percolation Test Report of pre-Phase 2 existing soils, which characterized the majority of soils onsite as having an in-situ infiltration capacity of moderate to very well-drained. Uncompacted subsoil samples indicated $2.25 \mathrm{in} / \mathrm{hr}$ infiltration rates, which were defined as moderate.

The completed design incorporated treatment swales at areas of $5 \%$ or less slope, and conveyance swales at areas of more than $5 \%$ slope. Drainage areas were separated into 11 micro bio-retention facility designations. The total rainfall treated was calculated by using the 
ESDv equation outlined in the ESD Process and Computations handbook: $\mathrm{P}_{\mathrm{E}}=\frac{12 \times \mathrm{ESD}_{\mathrm{v}}}{\mathrm{R}_{\mathrm{v}} \times \mathrm{A}}$, with $\mathrm{Pe}=$ treated rainfall amount, $\mathrm{A}=$ area, $\mathrm{Rv}=$ volumetric runoff coefficient. Where micro-scale practices were used, these volumes were added together to determine the volume for the entire ESD system (Fig. 2).

\begin{tabular}{|c|c|c|c|c|}
\hline \multicolumn{5}{|c|}{ ESDV SUMMARY TABLE } \\
\hline $\begin{array}{l}\text { MICRO BIO-RETENTION } \\
\text { FACILITY DESIGNATION }\end{array}$ & $\begin{array}{l}\text { DRAINAGE AREA } \\
\text { (Sq.ft.) }\end{array}$ & $\begin{array}{l}\text { IMPERVIOUS AREA } \\
\text { (Sq.ft.) }\end{array}$ & $\begin{array}{l}\text { ESD VOLUME PROVIDED } \\
\text { (cu.ft.) }\end{array}$ & PE ACHIEVED (in.) \\
\hline MBF \# 1 & 19861 Sq.ft. & 16403 Sq.ft. & $3427 \mathrm{Cu} . \mathrm{Ft}$. & $2.60 \mathrm{in}$. \\
\hline MBF\# 2 & 18660 Sq.ft. & 15143 Sq.ft. & 3109 Cu.Ft. & $2.60 \mathrm{ln}$. \\
\hline MBF \# 3 & 20057 Sq.ft. & 14957 Sq.ft. & 3108 Cu.Ft. & $2.60 \mathrm{ln}$. \\
\hline$M B F \# 4$ & 19850 Sq.ft. & 14318 Sq.ft. & 3030 Cu.Ft. & $2.60 \mathrm{in}$. \\
\hline MBF \# 5 & 19736 Sq.ft. & 14642 Sq.ft. & $3030 \mathrm{Cu} . \mathrm{Ft}$. & $2.50 \mathrm{ln}$. \\
\hline$M B F=6$ & 16188 Sq.ft. & 12385 Sq.ft. & 2557 Cu.Ft. & $2.60 \mathrm{In}$. \\
\hline$M B F \# 7$ & 16485 Sq.ft. & 12465 Sq.ft. & 2610 Cu.Ft. & $2.60 \mathrm{in}$. \\
\hline$M B F \# 8$ & 15130 Sq.ft. & 7674 Sq.ft. & 1681 Cu.Ft. & $2.60 \mathrm{in}$. \\
\hline MBF\# 9 & 15879 Sq.ft. & 8119 Sq.ft. & 1738 Cu.Ft. & $2.60 \mathrm{ln}$. \\
\hline MBF\# 10 & 19150 Sq.ft. & 11022 Sq.ft. & 1787 Cu.Ft. & $2.60 \mathrm{in}$. \\
\hline MBF \# 11 & 11523 Sq.ft. & 5755 Sq.ft. & 1227 Cu.Ft. & $2.60 \mathrm{ln}$. \\
\hline PERVIOUS PAVEMENT & - & - & $4343 \mathrm{Cu} . \mathrm{Ft}$. & - \\
\hline CISTERN & 213831 Sq.ft. & 83156 Sq.ft. & 17605 Cu.Ft. & - \\
\hline \multicolumn{3}{|c|}{ TOTAL ESD VOLUME PROVIDED } & 49252 Cu.Ft & $1.00 \mathrm{ln}$ \\
\hline \multicolumn{5}{|c|}{ Treatment Required $=\quad 49,194 \mathrm{cf}$} \\
\hline \multicolumn{5}{|c|}{ Treatment Provided $=$} \\
\hline \multicolumn{5}{|c|}{ Rainfall Treated, $\mathrm{P}_{\mathrm{E}=}$} \\
\hline
\end{tabular}

Fig. 2: ESDv Summary for Phase 2. Source: Vika Maryland

\section{Limitations:}

These calculations are projections. Stormwater monitoring equipment has been installed to measure water flow coming out of cistern, but it does not measure level of cistern.

These calculations also likely greatly underestimate the amount of stormwater managed on site and may not include natural areas that were not graded. It also may not include ponds.

\section{Sources:}

Construction documents provided by PWP, prepared by Vika Maryland and PWP. University of Maryland, Environmental Site Design (ESD) Process \& Computations, 2010. Accessed July 10, 2019. 
- Intercepts 50,300 cu ft of stormwater runoff annually in 9,026 newly-planted trees.

Method:

i-Tree Eco v6 is a model that uses tree measurements and characteristics to estimate ecosystem services of urban and rural forests. ${ }^{3}$ It was developed by the US Forest Service, Davey Tree Expert Company, Arborday Foundation, Society of Municipal Arborists, International Society of Arboriculture, Casey Trees, and SUNY College of Environmental Science and Forestry. Please see the carbon sequestration Benefit below for explanation of full methodology, calculations, and limitations for the i-Tree analysis.

During storm events, trees and forests have the capacity to intercept rainfall through their canopies, thus reducing stormwater runoff. In urban contexts, trees reduce surface runoff on impervious surfaces. Additionally, trees are integral to the hydrological cycle in part because of their ability to reduce and slow runoff directed to streams, lakes, rivers, and wetlands, and preventing erosion by stabilizing soil.

Limitations:

See Limitations of carbon sequestration Benefit below.

Sources:

Tree inventories provided by PWP

iTree Eco i-Tree Software Suite v. 6.0.16. Accessed July 15, 2019.

https://www.itreetools.org/tools/i-tree-eco

- Restored riparian habitat along 2.7 miles of streams. Over 20 native species were planted along streams including trees, shrubs, ferns, and emergent wetland species.

\section{Calculations:}

Glenstone has been leading a multi-year effort to restore and improve the streams that flow through the property. This has been spearheaded through a public-private partnership in which both Montgomery County and Glenstone share stream reconstruction project construction costs, but Glenstone is responsible for project coordination and sequencing. The restoration effort is a collaborative one, involving long-term stream quality testing and design and construction reviews with Glenstone, Montgomery County planning officials, Maryland Department of the Environment and the design team. The third phase of this work, including ongoing water quality testing, is scheduled to be completed in 2019.

${ }^{3}$ https://www.itreetools.org/tools/i-tree-eco/i-tree-eco-overview 


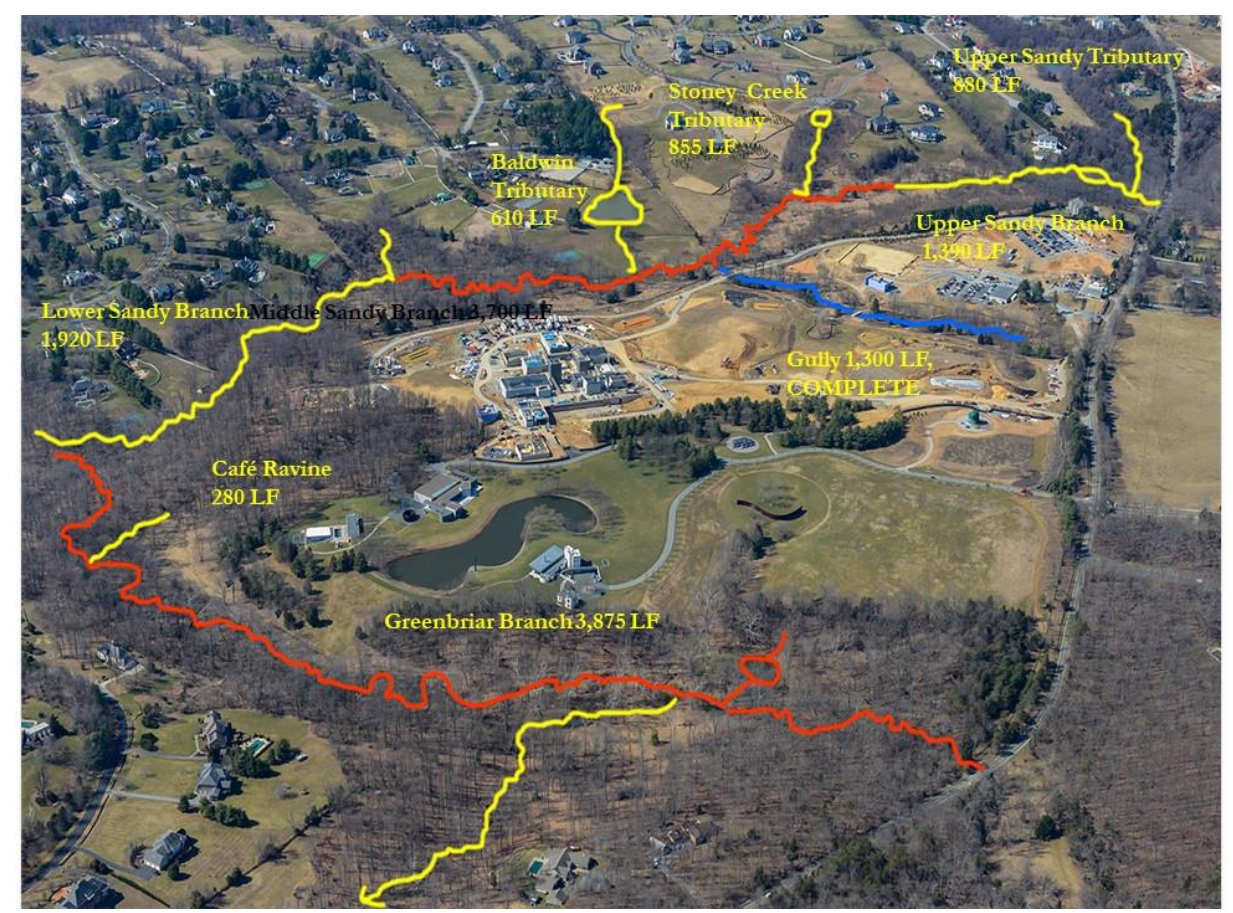

Fig. 3: Map of stream restoration efforts at Glenstone. Source: PWP

Fig. 3 demonstrates completed and planned restoration areas of the various creeks and tributaries surrounding Glenstone. Restored stream lengths of 2.7 miles, or 14,000 linear feet, provided by PWP Landscape Architecture.

13 species of canopy trees, understory trees, shrubs, and ferns were planted on the Greenbriar Branch and 14 species of canopy trees, understory trees, shrubs, and wetland emergent species were planted on the Sandy Branch. The total unique species planted in the two branches totals 20 (Fig. 4). 
Stream Restoration Plant List

\begin{tabular}{|c|c|c|c|c|c|}
\hline & Species & Common Name & Symbol & Grade & Comments \\
\hline \multirow[t]{13}{*}{ Canopy Trees } & & & & 1-1.5" caliper & \\
\hline & Acer rubrum & Red Maple & AcRu & & \\
\hline & Carya ovata & Shagbark Hickory & $\mathrm{CaOv}$ & & \\
\hline & Celtis occidentalis & Hackberry & $\mathrm{CeOc}$ & & \\
\hline & Fagus grandifolia & American Beech & $\mathrm{FaGr}$ & & \\
\hline & Liquidamber styraciflua & Sweet Gum & LiSt & & \\
\hline & Nyssa sylvatica & Black Gum & NySy & & \\
\hline & Liriodendron tulipifera & Tuliptree & LiTu & & \\
\hline & Platanus occidentalis & American Sycamore & PIOc & & \\
\hline & Quercus alba & White Oak & QuAl & & \\
\hline & Quercus bicolor & Swamp White Oak & QuBi & & \\
\hline & Quercus imbricaria & Shingle Oak & Qulm & & \\
\hline & Quercus palustris & Pin Oak & QuPa & & \\
\hline \multirow[t]{9}{*}{ Understory Trees } & & & & $1 "$ caliper & \\
\hline & Alnus serrulata & Smooth Alder & Alse & & \\
\hline & Amelanchier sp. & Serviceberry & $\mathrm{AmCa}$ & & \\
\hline & Betula nigra & River Birch & $\mathrm{BeNi}$ & & \\
\hline & Carpinus caroliniana & Ironwood & $\mathrm{CaCa}$ & & \\
\hline & Cercis canadensis & Redbud & $\mathrm{CeCa}$ & & \\
\hline & Diospyros virginica & Persimmon & Divi & & \\
\hline & Prunus serotina & Black Cherry & PrSe & & \\
\hline & Robinia pseudoacacia & Black locust & RoPs & & \\
\hline \multirow[t]{6}{*}{ Shrubs } & & & & 6 ' height & \\
\hline & Ilex verticillata & Winterberry & IIVe & & \\
\hline & Lindera benzoin & Spicebush & LiBe & & \\
\hline & Viburnum prunifolium & Blackhaw Viburnum & ViPr & & \\
\hline & Asimina triloba & Paw Paw & AsTr & & \\
\hline & & & & 3 ' height, \#3 container & \\
\hline \multicolumn{6}{|l|}{ Groundcover } \\
\hline & Caltha palustris & Marsh Marigold & $\mathrm{CaPa}$ & 4" container & \\
\hline & Carex stricta & Tussock Sedge & CaSt & & \\
\hline & Carex vulpinoidea & Fox Sedge & $\mathrm{CaVu}$ & & \\
\hline & Iris virginica & Blue Iris & IrVi & & \\
\hline & Matteuccia struthiopteris & Ostrich fern & MaSt & & \\
\hline & Osmunda regalis & Royal Fern & OsRe & & \\
\hline & Polystichum acrostichoides & Christmas Fern & PoAc & & \\
\hline & Saururus cernuus & Lizardtail & $\mathrm{SaCe}$ & & \\
\hline & Thelypteris palustris & Marsh Fern & $\mathrm{ThPa}$ & & \\
\hline \multicolumn{6}{|l|}{ Livestakes } \\
\hline & Cephalanthus occidentalis & Buttonbush & Ceph & & \\
\hline & Cornus racemosa & Grey Dogwood & CoRa & & \\
\hline & Salix sp. & Willow & LiBe & & \\
\hline
\end{tabular}

Fig. 4: Plant list for riparian restoration at Glenstone. Source: PWP Landscape Architecture

\section{Source:}

Linear feet restored and plant lists provided by PWP Landscape Architecture

\section{Limitations:}

Not independently verified by the CSI research team.

- Increased ecological integrity of plant communities as demonstrated by an adjusted Floristic Quality Index (FQI) score of 54, as compared an FQI score of 0 for a turf mix typically used in subdivisions similar to the site's previous condition. An FQI above 35 is considered to be "natural area" quality.

Methods:

The Floristic Quality Index (FQI) was developed to provide an objective assessment of the 
ecological integrity of plant communities based on species composition. ${ }^{4} \mathrm{FQI}$ was originally defined by Swink and Wilhelm in Plants of the Chicago Region, 1994. The calculation is based on coefficients of conservatism ( $\mathrm{C}$ value), assigned to individual plant species based on several qualities.

The Floristic Quality Index (FQI) is calculated by multiplying the mean C value by the square root of the total number of species:

$$
I=\bar{C} \sqrt{n},
$$

To assess sites with higher levels of human disturbance that takes into account the ecological value that can be offered by adapted non-native species, the Adjusted FQI was developed (Miller \& Wardrop 2006):

$I^{f}=100\left(\frac{\overline{C_{n}}}{10}\right)\left(\frac{\sqrt{n_{n}}}{\sqrt{n_{n}}}\right)$,

A higher score typically represents a higher quality environment. The index was calculated by adding each species included in planting mixes for meadow areas and areas that were formerly or would traditionally be planted with turf to the species inventory in the Floristic Quality Assessment Inventory Assessment tool. These areas consisted of: the parking groves, arrival gallery, meadows, and museum entrance.

\section{Calculations:}

FQI was calculated for two site conditions:

- Typical turf mix used in region for subdivision plots (pre-existing site)

- As designed Phase 2 construction for parking groves, meadows, arrival gallery, meadows, museum entrance

The similar subdivision plot in Potomac, MD was used as a comparison, as this condition was the existing condition before Phase 1 construction commenced.

For as designed Phase 1 and 2 construction, plant species were gathered from planting plans and surveys from PWP.

\footnotetext{
${ }^{4}$ https://besjournals.onlinelibrary.wiley.com/doi/full/10.1111/2041-210X.12491
} 


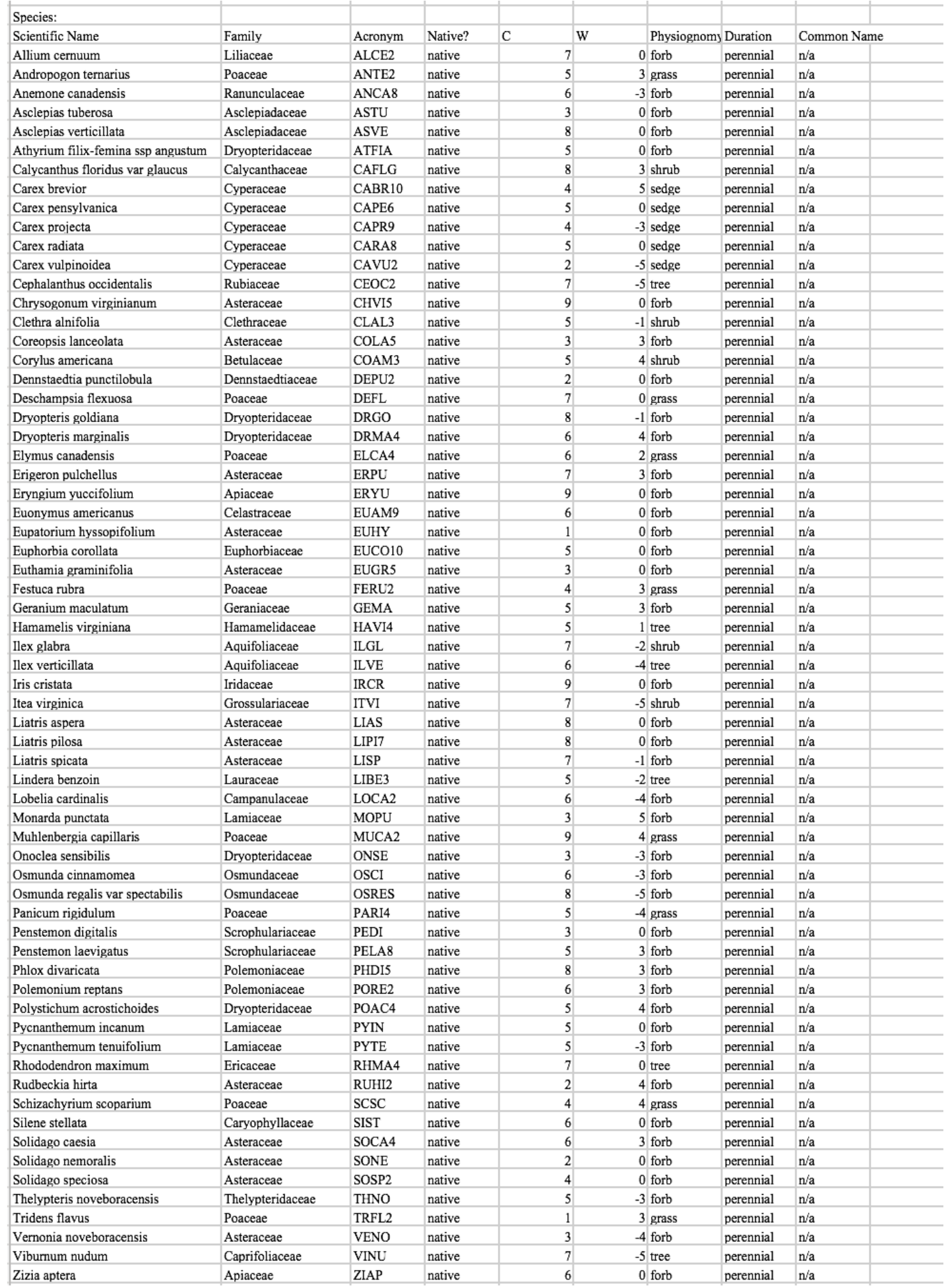

Fig. 5: FQI Analysis by the CSI research team

Limitations:

65 species of 95 species planted were included in the FQI analysis. 30 species used in the planting palette were not available in the Floristic Quality Assessment database: Deschampsia 
cespitosa, Zizia aureus, Secale cereale, Aster oblongifolius, Hordeum jubatum, Aster divaricatus, Helianthus angustifolius, Hordeum jubatum, Aster macrophyllus, Geum fragarioides, Aster azureus, Carex bebbii, Aster laevis, Solidago rigida, Eupatorium coelestinum, Eupatorium fistulosum, Aster patens, Coreopsis major, Baptisia alba, Callisia rosea, Hamamelis $x$ intermedia, Myrica pennsylvanica, Osmanthus americanus, Prunus laurocerasus, Festuca obtusa, Tradescantia virginiana, Smilacina racemosa, Eupatorium dubiumm Amsonia hubrichtii, Fothergilla gardenii. Comparable species were not added to the analysis. This means that the FQI is likely underestimated.

Sources:

Universal Floristic Quality Assessment. Accessed June 26, 2019. https://universalfqa.org/ https://www.plantmaps.com/interactive-maryland-ecoregions-14-map.php

- Sequesters an estimated 22.03 tons of atmospheric carbon annually in 9,026 newly-planted trees, with 234 tons of carbon stored in their biomass. 20 years after planting, these trees will sequester 36.8 tons per year.

Methods:

Many existing trees prior to Phase 1 and 2 construction were unhealthy, scrubby, or weedy, and many had been planted according to the site's past use as a subdivision. After an extensive tree inventory, 400 trees were identified to be relocated. These 400 relocated trees are not included in this analysis, but would likely provide significant carbon sequestration and storage. A reforestation plan resulted in the planting of more than 9,200 trees from Phases 1-2. Portions of the site were repurposed as a nursery during construction to support this effort.

$\mathrm{i}$-Tree Eco v6 is a model that uses tree measurements and characteristics to estimate ecosystem services of urban and rural forests. ${ }^{5}$ It was developed by the US Forest Service, Davey Tree Expert Company, Arborday Foundation, Society of Municipal Arborists, International Society of Arboriculture, Casey Trees, and SUNY College of Environmental Science and Forestry. As extensive planting lists of existing and newly-planted trees are available for Phases 1 and 2, the research team chose to analyze a complete inventory of trees through i-Tree Eco to determine values for each tree and overall.

Weather data was used from the Dulles, VA station. 2015 weather data was used, which was the most recent available. The data input for each specimen were: species DBH at time of planting, and land use type (Institutional).

A planting log was provided by PWP, and it included records from the time of planting for over 6,241 trees planted from fall 2014-spring 2018 at Glenstone (including species, DBH at time of planting, and date of planting).

This data was cleaned by:

- Removing records with no species noted

- Removing $\sim 45$ records where species code was unclear

${ }^{5}$ https://www.itreetools.org/tools/i-tree-eco/i-tree-eco-overview 
- For those records that provided height instead of DBH, assigning a 3" DBH (at time of planting) as a conservative estimate

Ultimately 6,170 trees from the planting log were accepted in i-Tree Eco's model.

According to PWP, the total number of trees planted in Phase I and after was1,700 trees Planted in Phase II and after was 7,500 trees, for a total of 9,200 trees planted.

Because the data for individual trees was incomplete $(6,170$ trees could be entered into i-Tree from the planting log as described above), the missing species were entered to make up the additional 3,030 . This was done by entering species in numbers correlating to the percentage makeup of the 6,170 records. Each species entered was assigned a DBH that was an average of the existing records for that species.

The model provided estimates of total carbon stores and net carbon annually sequestered by trees on-site, both highly significant benefits of urban forests and one of the most important methods in reducing the amount of $\mathrm{CO} 2$ in the atmosphere and reducing the impacts of climate change. Carbon sequestration is the process through which carbon dioxide is removed from the atmosphere and held in solid form, while carbon storage is the long-term storage of carbon. Trees store carbon in their leaves, wood, and roots. It also provided estimates of stormwater intercepted by tree canopies (see stormwater Benefit above).

i-Tree Eco's Forecast was used for 20-year projections. Number of days per year without frost were assumed to be 210 . Base annual mortality rate for healthy trees was assumed $3.0 \%$, base annual mortality rate for sick trees $13.1 \%$, and base annual mortality rate for dying trees is $50 \%$

\section{Calculations:}

As reported by PWP:

Planted in Phase I and after: 1,700 trees with an average caliper (as of 2019) estimated at 8" Planted in Phase II and after: 7,500 trees with an average caliper (as of 2019) estimated at 6"

9,200 trees $-6,170$ (records able to be processed in i-Tree after cleaning) $=3,030$ trees entered with species makeup \% estimated for a total of 9,200 trees analyzed. Not all records were accepted by i-Tree, so the total number processed was 9,026 trees.

Inputs per specimen: - Species - Diameter - Land Use (Industrial)

\section{Limitations:}

Tree planting data is noted to be inconsistent for the duration of the project due to human error. This tree count does not include Stony Creek, a property later acquired by Glenstone, where approximately 2,000 trees were planted.

The tree planting data did not include additional information such as tree condition, height, and crown condition that improve the accuracy of i-Tree Eco results. Additionally, calculations are based on caliper size at time of planting. The carbon sequestered by trees on-site will increase 
as young trees mature (as noted in the 20 year projection). If trees die out, carbon sequestration potential will decrease. Without tree canopy data entered (it was unavailable), the model assumes that all trees entered are alive and growing (even if trees may be dead or declining).

Quercus nuttallii was not available in i-Tree, so Quercus schumardii was used as a proxy due to its similar structure and leaf composition.

Using "institutional" as land use type is the closest approximation to Glenstone's unique landscape typology.

A limitation of the 20-year projections is that the trees entered into i-Tree were all planted over many years, from fall 2014 to spring 2018 - meaning that annual carbon sequestration by the entire dataset of trees is a moving target. Without intensive use of i-Tree and processing each year separately, the annual rates of carbon sequestration are not entirely accurate and should be considered estimates.

\section{Sources:}

Tree Inventories provided by PWP i-Tree Canopy. i-Tree Software Suite v6.1. (n.d.). Web. Accessed July 15, 2019. http://www.itreetools.org

iTree Eco. i-Tree Software Suite v. 6.0.16. Accessed July 15, 2019. https://www.itreetools.org/tools/i-tree-eco

- Diverts approximately 10.5 tons of organic food waste from landfills annually by composting and reusing it on-site. This saves an estimated $\$ 6,400$ annually when compared to conventional waste management practices.

\section{Methods:}

Organic food waste is weighed and composted each month from the site's café and employee cafeteria. Compost is reused on-site and in compost tea used to feed and irrigate landscape plants. This practice diverts approximately $21,000 \mathrm{lbs}$ (10.5 tons) of organic waste from landfilling each year. Composting of organic food waste was compared to the services of Waste Management, a waste management contractor servicing Potomac.

Calculations:

Conventional Waste Management Fees:

Waste Pickup (4 yard garbage dumpster): \$529.40 per month (1 pickup per week) $529.40 \times 12=\$ 6,352.80$ per year in disposing of organic food waste using conventional waste management

\section{Sources:}

Waste quantities provided by Glenstone

Service quote provided by Waste Management. Accessed July 29, 2019. https://www.wm.com 
Limitations:

Food waste weight is an estimate. Plant debris is also composted, but not weighed before adding to compost. Waste service comparison is an estimate of one service provider in the region, cost of service can vary based on location, quantity of waste, and frequency of pickup.

- Diverted an estimated 247,000 Ibs of construction and demolition debris by reclaiming $95 \%$ of building materials from 20 former residential properties.

Methods:

Glenstone and PWP have worked with property owners to purchase and demolish 20 homes located in sensitive areas along the stream tributaries that run through Glenstone. In doing so, they hope to reduce the amount of stormwater runoff discharging into the streams. In addition, Glenstone is working with three property owners on reforestation and stream restoration projects located on their properties.

Based on data provided by Glenstone, estimated square footage of homes demolished, and the weighted average estimate of construction waste produced during demolition, an estimated quantity of debris diverted from landfilling was calculated. Many of these materials were donated to nonprofit organizations and repurposed.

\section{Calculations:}

Weighted average estimate of overall construction waste produced during demolition: 4.34 lbs / square foot ${ }^{6}$

Estimated square footage of demolished homes: 7,500 square feet $260,400 \mathrm{lbs}$ (construction and demolition waste) x .95 (rate of recycling) = estimated 247,380 lbs diverted from landfill

\section{Limitations:}

Quantity of building materials is an estimation. Numbers not independently verified by the research team.

\section{Sources:}

Data provided by Glenstone

Environmental Protection Agency, Estimating 2003 Building-Related Construction and Demolition Materials Amounts, 2003. Accessed 7/25/19.

https://www.epa.gov/sites/production/files/2017-

09/documents/estimating2003buildingrelatedcanddmaterialsamounts.pdf

\footnotetext{
${ }^{6}$ https://www.epa.gov/sites/production/files/201709/documents/estimating2003buildingrelatedcanddmaterialsamounts.pdf
} 


\section{Social Benefits}

\section{Overall Methods for Survey:}

A multiple-choice survey was developed and incorporated into Glenstone's post-visit user survey, administered online via email. The surveys were emailed to all Glenstone visitors who reserved tickets using email between June 1, 2019 and June 30, 2019. Over this period of time, there were 856 respondents $(\mathrm{N})$.

\section{Overall Calculations for Survey:}

Example Calculation (for all listed survey results):

Question: Did your experience with the landscape at Glenstone increase your feeling of emotional well-being during your recent visit?

\begin{tabular}{|l|l|l|}
\hline Answer Choice & Responses & \\
\hline Yes & $88.10 \%$ & 733 \\
\hline Neutral & $10.10 \%$ & 84 \\
\hline No & $1.80 \%$ & 15 \\
\hline & Answered & 832 \\
\hline & Skipped & 24 \\
\hline
\end{tabular}

$88.10 \%$ of respondents $(\mathrm{N}=832)$ felt an increased sense of emotional well-being during their visit. $733 / 832=.881 \times 100=88.1 \%$

\section{Sources for Survey:}

Survey questionnaire (see Appendix A).

\section{Limitations of Survey:}

The survey is administered only to the individuals who reserved tickets online. It was not sent to a visitor who accompanied the individuals who reserved the tickets. Respondents are sent an email after their visit to Glenstone where they can fill out a user experience survey, administered by Glenstone. The UVA research team questions were added to the end of the Glenstone user experience survey, which can be exited without submitting responses at any point during the survey.

- Creates a sense of connection to the landscape, with $95 \%$ of 833 surveyed visitors saying they felt very or extremely engaged and 92\% saying that they engaged with the Glenstone landscape more than they typically do at museums.

\section{Methods:}

Notable survey results are as follows:

$54.86 \%$ of respondents $(\mathrm{N}=833)$ reported that they felt extremely connected to the landscape at Glenstone.

$40.22 \%$ of respondents $(\mathrm{N}=833)$ reported that they felt very connected to the landscape at Glenstone. 
$\mathrm{N}=833,21$ respondents skipped this question.

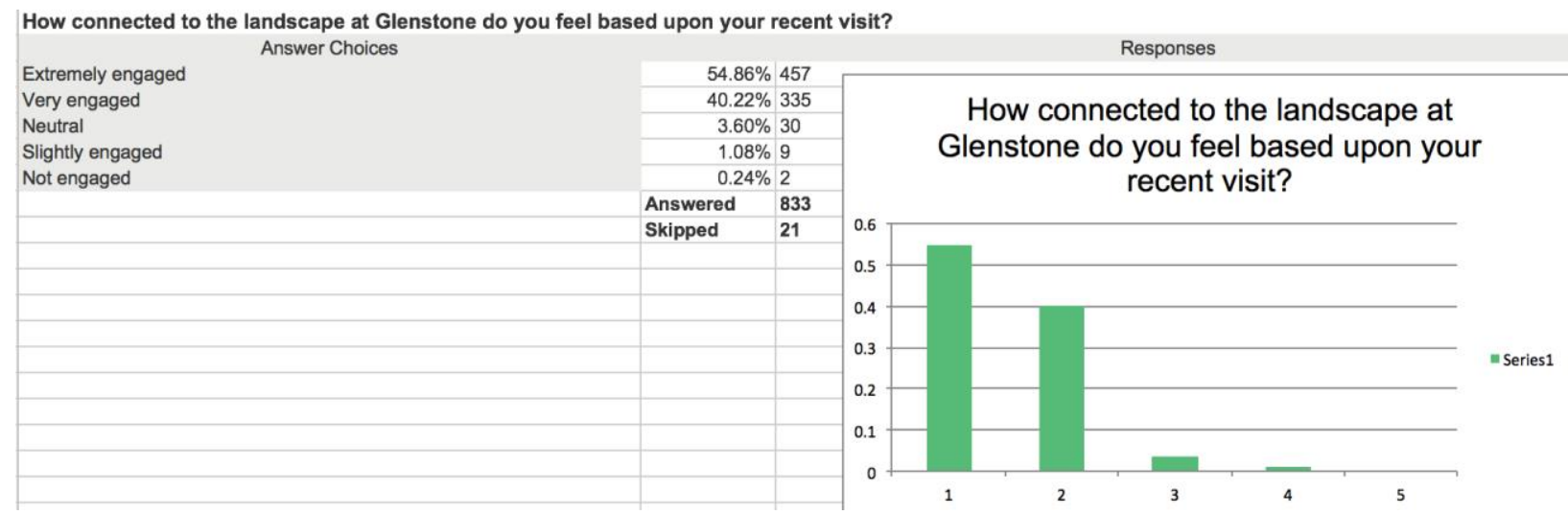

Fig 6: Survey responses

$30.60 \%$ of respondents $(\mathrm{N}=830$ ) reported that they engaged with the landscape at Glenstone more than they had at any other museum.

$61.69 \%$ of respondents $(\mathrm{N}=830$ ) reported that they engaged with the landscape at Glenstone more than they typically do at museums.

$\mathrm{N}=830,24$ respondents skipped this question.

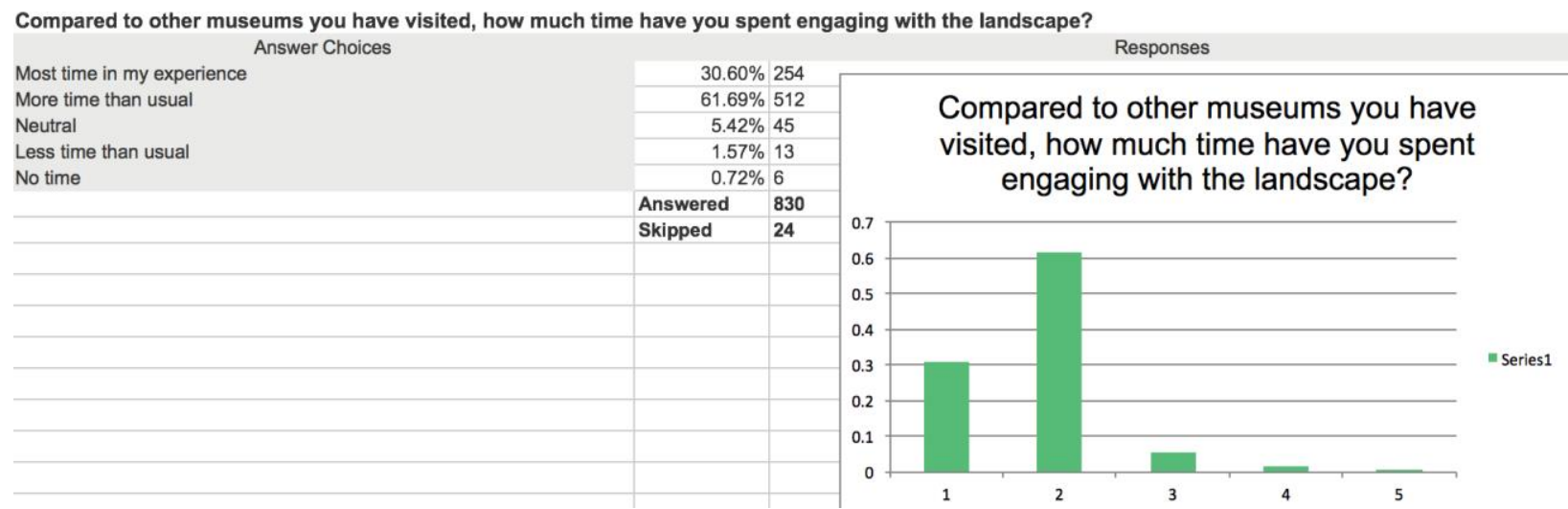

Fig 7: Survey responses

Calculations: See overall calculations.

Sources: User survey

Limitations: See overall limitations.

- Increases feelings of emotional well-being according to $88 \%$ of 832 surveyed visitors.

Methods: Notable survey results are as follows: 
$88.10 \%$ of respondents $(\mathrm{N}=832)$ reported that their experience with the landscape at Glenstone increased their feeling of emotional well-being during their visit.

$\mathrm{N}=832,24$ respondents skipped this question.

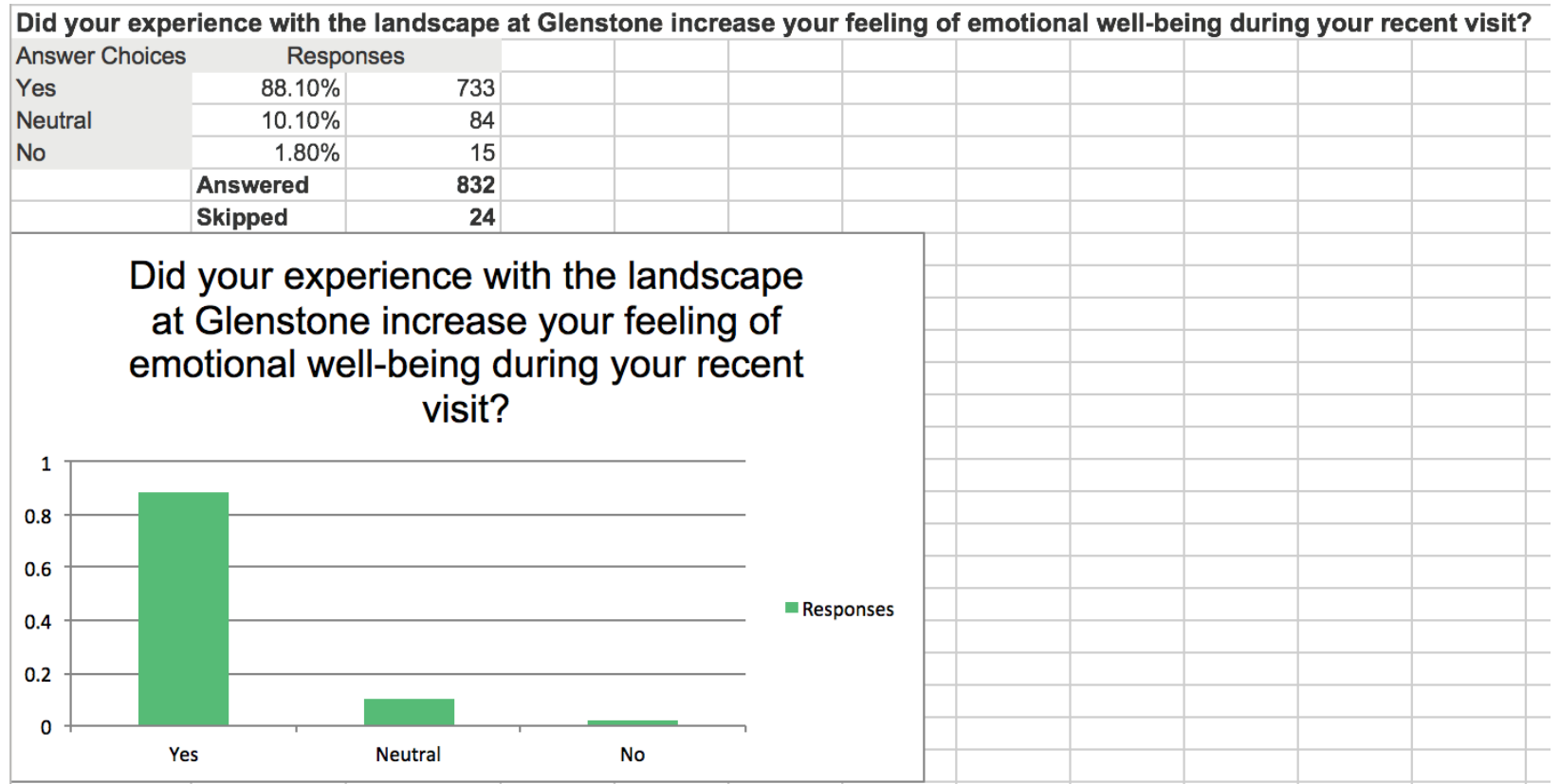

Fig 8: Survey responses

Calculations: See overall calculations.

Sources: User Survey

Limitations: See overall limitations.

- Provides educational value and jobs for recent graduates through the guide program, currently employing $\mathbf{4 0}$ guides who are trained in sustainability, horticulture, and other landscape topics.

Methods:

The Emerging Professionals Program and guide program for recent graduates seeking careers in museums or other cultural fields supports and trains young professionals. As part of their training, all guides are trained in the landscape at Glenstone in order to better identify visitor questions.

Calculations: Not applicable for this benefit.

Sources:

Employment data was provided by Glenstone.

Glenstone Whitepaper on Conservation 
Limitations:

Not independently verified by the research team.

- Catalyzed the creation of one new bus route serving Glenstone visitors and staff as well as local residents. In 2019, over 6,000 visitors arrived at Glenstone on the bus.

\section{Calculations:}

Representatives from Glenstone directly advocated with local WMATA authorities for the creation of a bus route to Glenstone and supported longstanding efforts to increase bus routes in the area. In 2014, representatives from Glenstone met with representatives of Tobytown, a historic African American community about 1.5 miles west of Glenstone and a Montgomery County council member to discuss a potential bus route for the area. It was not until November of 2016 that bus service was introduced as the "TobyTown Route 301" bus line. Initially, it stopped at Glenstone twice in the morning and twice in the afternoon, weekdays only, to accommodate Glenstone staff. In 2018, Glenstone staff met with county and Ride On bus officials to expand the route to accommodate daily Glenstone visitors. In January of 2019 , Glenstone began to offer automatic entry to Glenstone (which normally is done by reservation only) for visitors arriving by bus. The program was "instantly popular" and the program is planned to continue indefinitely. More than 6000 visitors arrived on the bus on 2019 (as of the beginning of the December 2019)

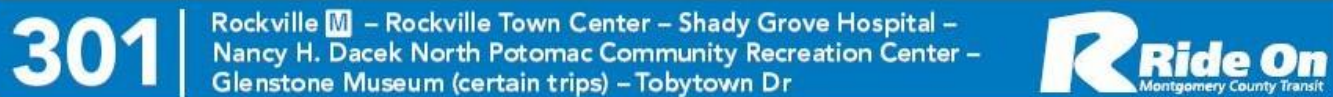

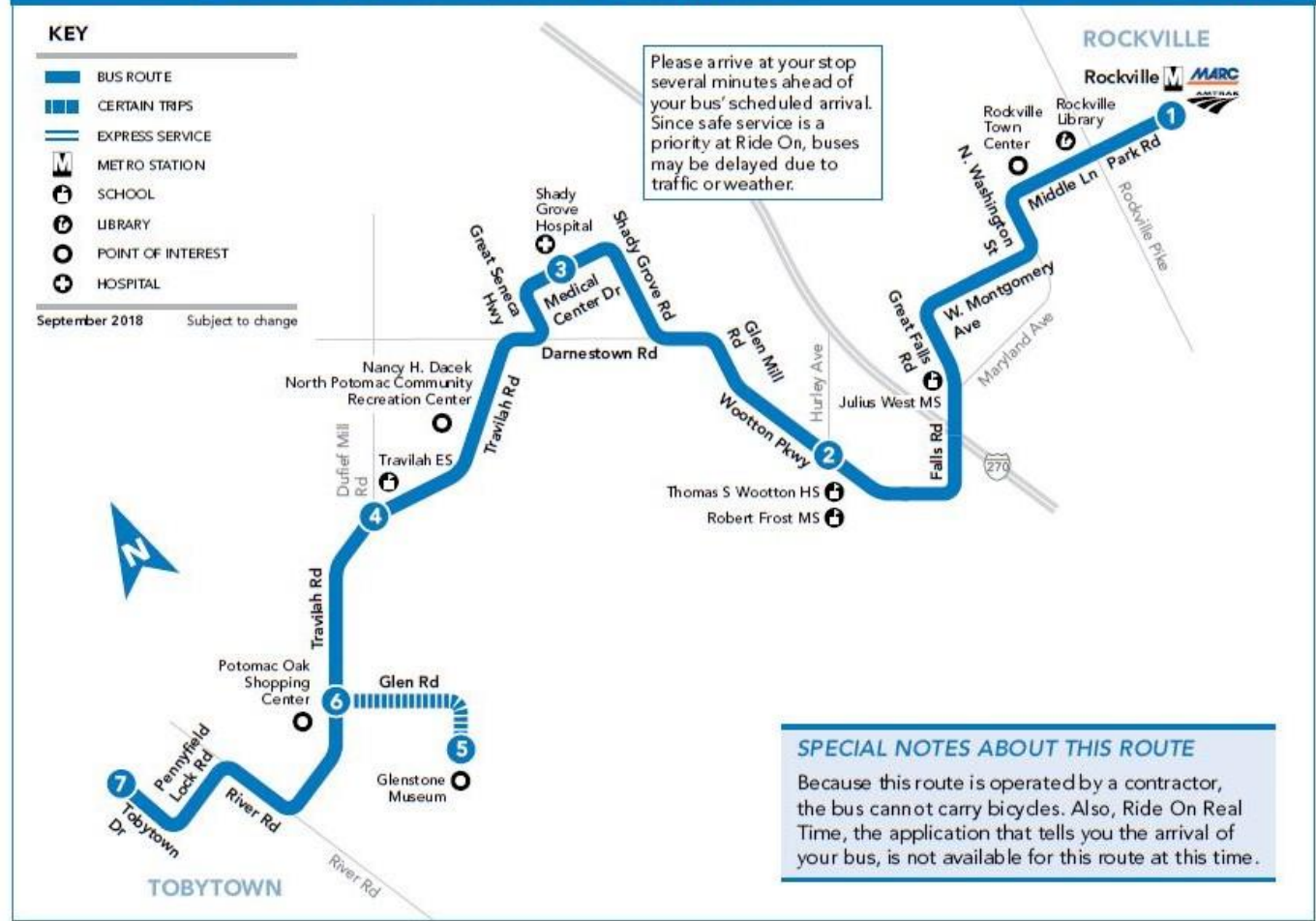

Fig 9: bus route to Glenstone and other stops as of Dec 2019 
As of December 2019, Glenstone is working with Ride On bus officials to consider a line that would connect Glenstone to downtown Potomac, which is served every 20 minutes by a DC Metro bus that connects to the Red Line train to DC.

\section{Sources:}

Personal communication with Paul Tukey, Chief Sustainability Officer at Glenstone. Email correspondence 12/13/2019.

- Impacts visitors early in their visit, according to $15 \%$ of 750 surveyed visitors who reported first feeling impacted by the landscape on entrance road, $22 \%$ at the parking lots, $7 \%$ at the Arrival Hall, and $47 \%$ on the walk from the Arrival Hall to the Pavilions.

Methods: See overall methods.

$\mathrm{N}=750,104$ respondents skipped this question.

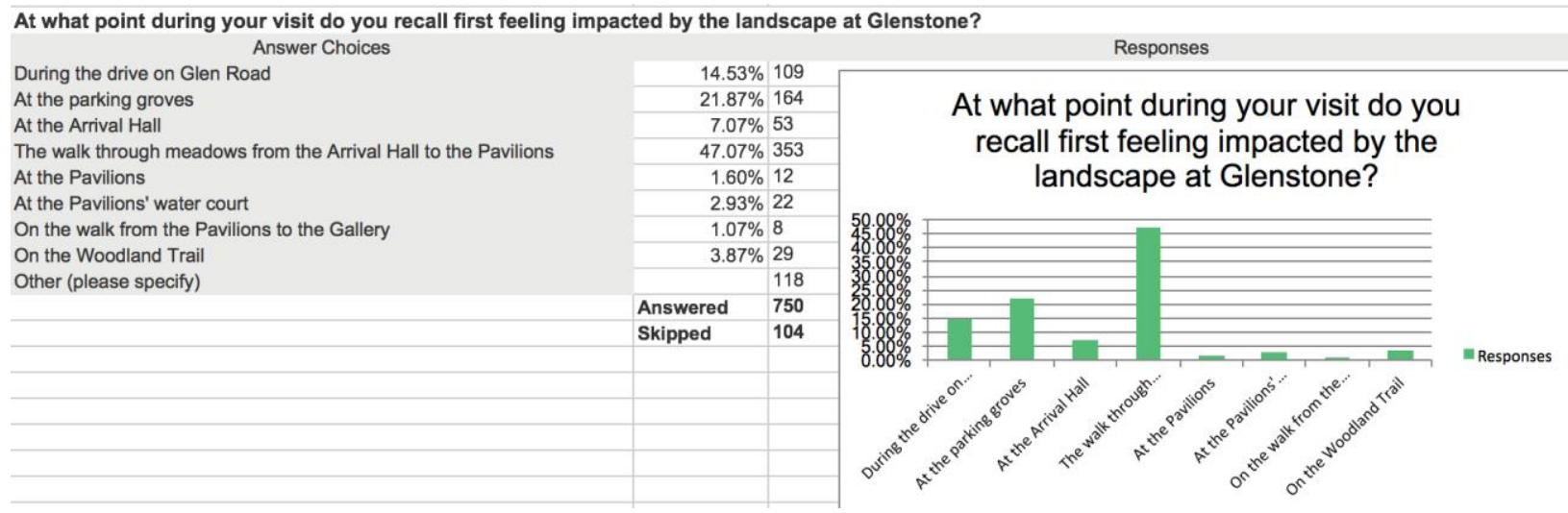

Fig 10: Survey responses

Calculations: See overall calculations. With a primary goal of Glenstone being to impact visitors with the landscape even before their arrival at the museums, understanding when visitors are impacted by Glenstone's landscape helps to understand whether that is achieved.

Sources: Survey data

Limitations: See overall limitations.

- Helped to legitimize and advance a Montgomery County-wide policy restricting the use of chemical lawn pesticides, with the policy upheld by court ruling in May 2019.

Calculations:

Prior to 2010, the landscape at Glenstone was maintained by practicing Integrated Pest Management, an ecosystem based strategy that relies on monitoring and pest control practices 
to manage pests economically. This maintenance strategy included the use of synthetic chemicals in fertilizers, as well was the application of chemical pesticides when treatment of insects, weed, algae, and fungal diseases was necessary. Since 2010, Glenstone has worked closely with Paul Tukey, now Chief Sustainability Officer at Glenstone. Glenstone now uses only naturally derived fertilizers and pest control products in tandem with sustainable landscape management practices including: onsite compost production, application of compost tea, interplanting areas of turf with clover, and hand-pulling, flaming, tarping, and weed-whacking. Experimentation and testing of sustainable management methods has allowed Glenstone to determine the most successful maintenance techniques for the site.

The success of organic landscape maintenance practices at Glenstone helped to legitimize and advance a county-wide policy restricting the use of chemical lawn pesticides on private lawns and childcare facility grounds. The policy was upheld by court ruling in May 2019.

Sources:

https://www.montgomerycountymd.gov/lawns/law.html

\section{Economic Benefits}

- Saves an estimated \$160,000 annually in reduced mowing and maintenance costs by converting 91 acres of conventionally managed turf to meadow, fescue, and seeded understory.

\section{Methods:}

Glenstone has converted 82.8 acres of what was previously conventionally managed turf to meadows, seeded understory, "no mow" fescue turf, and limited areas of tall fescue turf. Current turf areas are managed with more sustainable practices: tall fescue grass is mowed to a height of 3-4" to reduce weeds, clover is allowed to grow in the grass to add nitrogen to the soil, and grass clippings are applied to the grass to add nutrients. Converting former turf to meadow and seeded understory reduces the need for mowing, with meadow being mown once a year.

An interview with the Grounds Superintendent disclosed that average monthly maintenance for traditional turf onsite is 14.7 hours per acre, and 5 hours per acre for unmowed areas like the meadow and seeded understory plantings. Glenstone has approximately 5.5 acres of turf, 2 acres of no mow turf, 45 acres of meadow, and 30 acres of seeded understory.

To quantify how much is saved by transition landscape types and management techniques, the acreage of previously conventional turf ( 82 acres) was multiplied by monthly cost per acre to show the total maintenance cost if the site was conventional turf. This was compared to the same calculation for the current site condition. The difference between these two amounts shows the total amount saved annually by planting native and no-mow vegetation on 48.8 acres of the site.

Calculations:

91 acres of previous turf and pasture converted to meadow 
Labor calculations:

Average labor per month, mowed turf: 14.7 hours per acre

Average labor per month, no mow turf + meadow + seeded understory: 5 hours per acre

Average cost of labor, mowing: $\$ 18 /$ hour

Conventional mowing labor calculation:

14.7 hours/acre/month $\times 82$ acres $\times 12$ months $=14,464.8$ hours of labor annually

$14,464.8 \times \$ 18 / \mathrm{hr}=\$ 260,352$ per year, conventional turf maintenance

Post-construction landscape labor calculation:

14.7 hours/acre/month $\times 5.5$ acres (conventional turf area) $\times 12$ months $=970.2$ hours of labor annually (turf)

5 hours/acre/month $\times 77$ acres (no-mow area) $\times 12$ months $=4,620$ hours of labor annually (nomow)

970.2 (turf) $+4,620$ (no-mow) $=\mathbf{5 , 5 9 0 . 2}$ hours of labor annually total

$5,590.2$ hours $\times \$ 18 / \mathrm{hr}=\$ \mathbf{1 0 0 , 6 2 4}$ per year, post-construction turf, seeded understory, and meadow maintenance

Conventional turf vs. no-mow and meadow cost savings:

$\$ 260,352-\$ 100,624=\$ 159,728$ savings annually

$14,464.8-5,590.2=\mathbf{8 , 8 7 5}$ hour reduction in labor annually

Sources:

Data provided by Glenstone

Area of turf and pasture converted to meadow provided by PWP Landscape Architecture

University of Maryland Extension, Home and Garden Information Center. Accessed June 29,

2019. https://extension.umd.edu/hgic/topics/mowing-grasscycling-lawns

\section{Limitations:}

These calculations only take into account mowing versus not mowing. They do not take into account additional management practices such as weeding, compost and nutrient application, and irrigation. These calculations also assume the same monthly mowing needs all year, although mowing varies from month to month.

- Creates landscape-related jobs for 15 full-time employees who manage the site and offer interpretive programs in Glenstone's Environmental Center. Glenstone Foundation employs approximately 150 people total.

\section{Methods:}

The Environmental Center at Glenstone opened in April, 2019, with a mission to "integrate experiential education based on the topics of natural landscape maintenance, synthetic chemical-free insect and disease control, alternative energy generation and conservation, soil 
biology and regeneration, composting and compost tea applications, recycling and waste management, greenhouse growing, streambed ecology and exotic invasive species control." 7

As the Environmental Center programming is still being finalized, data on visitors served is not yet available. Glenstone currently hosts school tours on Thursdays and Fridays, with one school tour per day. The Environmental Center will also start hosting school tours (expected to start in the near future).

Calculations: Not applicable for this benefit.

Sources:

Employment data was provided by Glenstone.

Glenstone Whitepaper on Conservation

Limitations:

Can change based on larger economic trends.

Cost Comparison

Over 40 acres of meadow restoration was originally going to be installed with live plants at a cost of $\$ 25,000$ per acre. Working with Glenstone Foundation and a meadow consultant, the design team was able to recommend a primarily seed-based establishment process, resulting in a savings of $\$ 20,000$ per acre.

Methods:

Hard-cost planting data was provided by PWP.

Calculations:

$\$ 25,000$ (live plant cost per acre) - $\$ 5,000$ (seed based cost per acre) $=\$ 20,000$ (savings)

Sources: PWP

Limitations:

There are no significant limitations associated with this method.

Originally proposed as standard asphalt (approximately $\$ 3.50$ per sf), Glenstone Foundation elected to make the staff parking area using permeable asphalt. While the cost was higher ( $\$ 5.55$ per sf), the benefits derived from improving stormwater quality, promoting infiltration, mitigation of heat island effects, and increased aquifer recharge were considered a higher priority.

Methods:

Hard-cost construction data provided by PWP.

${ }^{7}$ Glenstone Whitepaper on Conservation 
Calculations:

Hard-cost construction data provided by PWP.

Sources:

Data provided by PWP.

US Department of Transportation, Federal Highway Administration, TechBrief: Porous Asphalt Pavements with Stone Reservoirs. 2015. Accessed July 27, 2019.

https://www.fhwa.dot.gov/pavement/asphalt/pubs/hif15009.pdf

Limitations:

Hard data on quantifiable benefits of porous asphalt could not be located, but several publications, including the cited article from the US Department of Transportation, provide an overview of the benefits of permeable pavement. 